\title{
Induction of Resistance against Citrus Canker through Chemicals and Plant Activators
}

\author{
Waqas Ahmed Khan ${ }^{1}$, Muhammad Atiq ${ }^{1, *}$, Shahbaz Talib Sahi ${ }^{1}$, Awais Ahmed Khan ${ }^{2}$, Shafqat Ali ${ }^{1}$, \\ Muhammad Younas ${ }^{3}$, Yasir Ali ${ }^{1}$, Muhammad Rizwan Bashir ${ }^{4}$, Muhammad Sajid ${ }^{5}$ \\ ${ }^{1}$ Department of Plant Pathology, University of Agriculture, Faisalabad, Pakistan \\ ${ }^{2}$ University College of Agriculture, University of Sargodha, Sargodha, Pakistan \\ ${ }^{3}$ Directorate General Agriculture (E \& AR), Agriculture, Pakistan \\ ${ }^{4}$ Oil Seed Research Institute, Ayub Agriculture Research Institute (AARI), Faisalabad, Pakistan \\ ${ }^{5}$ Department of plant Pathology, Bahuddin Zakaryya University, Multan, Pakistan
}

Copyright $\bigcirc 2018$ by authors, all rights reserved. Authors agree that this article remains permanently open access under the terms of the Creative Commons Attribution License 4.0 International License

\begin{abstract}
The objective of present study was to evaluate the effect of copper hydroxide and flare at three concentrations $(0.1,0.2$ and $1 \%)$ and naphthalene acetic acid, salicylic acid, copper hydroxide alone and in combination (Flare + salicylic acid) at $0.75,1$ and $1.5 \%$ concentration against Xanthomonas axonopodis pv. citri in lab and greenhouse conditions respectively. Results showed that in lab condition maximum inhibition of bacterial growth was expressed by combination of flare and copper hydroxide, followed by Flare, copper hydroxide over control while in case of greenhouse experiment minimum disease incidence was expressed by combination of Flare + salicylic acid after 5, 10 and 15 days interval followed by flare, salicylic acid, naphthalene acetic acid and $\mathrm{Cu}(\mathrm{OH})_{2}$ as compared to control.
\end{abstract}

Keywords Citrus Canker, Copper Hydroxide, Naphthalene Acetic Acid, Resistance, Salicylic Acid, Xanthomonas axonopodis

\section{Introduction}

Asiatic citrus canker caused by Xanthomonas axonopodis pv. citri $(\mathrm{Xac})$ is the most destructive disease of citrus cultivars all over the world [14]. Elevated necrotic lesions on stem, twigs, leaves and fruits are the characteristic symptoms of the disease [13]. Several strategies like eradication and exclusion of pathogen were used to manage the disease [1] but the most suitable and economical way is the use of resistant varieties but when resistance is breakdown due to emergence of new lethal strains of pathogen then alternative way of management is the use of chemicals [7]. Multiple applications of copper based chemicals expressed adequate control of Xoc [6] due to prolonged residual activity as compared to other contact bactericides [15]. Copper oxychloride, copper hydroxide, copper sulphate and ammonia-copper carbonate are found to be highly effective against Xac [3]. Application of copper hydroxide and streptomycin sulphate throughout the season reduced the frequency of disease [7]. Three sprays per season of copper ammonium carbonate (CAC) or copper hydroxide with maneb reduced the lesions number on the surface of leaves and fruits (Das, 2003). However, continuous reliance on these compounds can cause mutation and emergence of aggressive races of Xac [15]. It is difficult to develop the most suitable and effective alternative of these compounds but now a days different biological and synthetic compounds having ability to manage numerous plant diseases without having any direct antibiotic effect are being used [10] for induction of resistance in citrus germplasm against Xac.

Induced resistance in plant cells is related with several defense responses like formation of pathogenesis-related proteins [2, 9, 12], alterations in physiology and biochemistry of cell wall $[20,24]$, production of reactive oxygen species (ROS), variations in activities of enzymes during oxidative stress [11, 23] and generation of phenylalanine ammonia-lyase (PAL) which is the fundamental enzyme of phenylpropanoid pathway [4, 23].

Plant activators like Salicylic acid (SA), ferric chloride $\left(\mathrm{FeCl}_{3}\right)$ and di-potassium hydrogen phosphate $\left(\mathrm{K}_{2} \mathrm{HPO}_{4}\right)$ are being used against Xac [6]. SA activates plant's own defense systems which provide long-lasting mechanisms of protection against broad spectrum of microorganisms [8, 18, 29, and 21]. Soil application of Acibenzolar-S-Methyl, Imidacloprid (ASM) and Thiamethoxam through drenching expressed SAR in citrus cultivars against citrus canker disease [7]. Because induced resistance through some chemicals is the most economical way therefore, present study was designed to evaluate different chemicals 
and plant activators alone and in combination against citrus canker disease.

\section{Materials and Methods}

\section{Plant Material}

Two year old citrus canker disease affected plants materials were obtained from nursery area of Institute of Horticultural Sciences, University of Agricultural Faisalabad.

\section{Preparation of Bacterial Cultural}

For preparation of bacterial culture infected tissues were cut into small pieces and were surface sterilized by using $0.1 \%$ mercuric chloride and then washed three times with sterilized distilled water. The small pieces of leaves were grounded by using sterilized pestle and mortar and mixture of $10 \mathrm{ml}$ was made by adding sterilized water followed by making the tenfold dilutions. From each dilution one $\mathrm{ml}$ was transferred to Petri plate and nutrient agar was poured in it. The plates were shaken gently to mix the medium. Plates were then incubated at $30{ }^{\circ} \mathrm{C}$ temperature. After 36 hours yellow colonies appeared in plates which were then shifted to agar slants to obtain pure cultures.

\section{Pathogenicity Test}

\section{Test Plants}

One year old grapefruit and sweet lime plants purchased from nursery area of Institute of Horticultural Science, University of Agriculture-Faisalabad were transplanted into pots containing $5 \%$ formalin sterilized soil. Additional amounts of fertilizer were added as needed and plants were watered as required.

\section{Inoculum Preparation and Inoculation}

Bacterial pure culture from citrus were tested for pathogenicity by inoculation of four week old nursery of grapefruit and sweet lime plants. Bacteria were grown for 72 hours in nutrient agar. Plates were flooded with sterile per litter of distilled water $(\mathrm{pH} 7.2)$ and the resulted suspension was adjusted to approximately $10^{8} \mathrm{cfu} / \mathrm{ml}$ by adopting plate counting technique [25]. Two hours before inoculation plants were irrigated and covered by polythene bags to generate humid conditions. Two weeks after inoculation symptomatic leaves were brought into lab and re-isolation of bacterium from infected tissues was made by the technique as described before for isolation and purification of pathogen. The morphological characters of bacterium were compared with the original culture used for inoculation.

\section{In-vitro Evaluation of Chemicals against Xanthomonas axonopodis pv. citri}

Copper hydroxide $\mathrm{Cu}(\mathrm{OH})_{2}$, Flare (Streptomycine sulphate $72 \%$ ) and their combination was evaluated using inhibition zone technique under Completely Randomized Design (CRD). For this purpose leaves infected with citrus canker disease were collected from nursery area of Institute of Horticultural Sciences, University of Agriculture, Faisalabad (UAF). For making bacterial suspension, these leaves were washed with tap water and infected portions were cut into small pieces, dip in sodium hypo chloride for some time then washed with sterilized water, homogenized them in sterilized pestle and mortar and their extract was passed through four layers of muslin cloth and filtered through Whatman filter paper No.1. Bacterial suspension containing $10^{8} \mathrm{cfu} / \mathrm{ml}$ were poured into petri dishes and were shaken to mix with the nutrient agar media. Sterilized cork borer of $1 \mathrm{~cm}$ diameter was used for making the wells into agar plates and different concentrations of chemicals were poured into wells which then were placed in refrigerator at $4^{\circ} \mathrm{C}$ for 24 hours. Then these petri plates were incubated at $28^{\circ} \mathrm{C}$ and inhibition zones were measured after 24,36 and 48 hours to incubation

\section{Evaluation of Different Concentrations of Chemicals and Plant Activators under Greenhouse Conditions}

One year old citrus plants were purchased from nursery area of Institute of horticultural sciences and were placed in pots, Department of Plant Pathology, University of Agriculture, Faisalabad. All the cultural practices were performed to keep the plants healthy and were sustained at $25-30{ }^{0} \mathrm{C}$ temperature with $65 \%$ relative humidity under greenhouse conditions. Plant activators like Salicylic acid (SA), Naphthalene acetic acid (NA) were sprayed before inoculation of plants with bacterium for induction of resistance. For the evaluation of chemicals (Copper hydroxide \& Streptomycin Sulphate) plants were first inoculated (spray inoculation) with bacterial suspension of $X a c$ and then sprayed with different concentrations of these chemicals whereas control plants were treated only with bacterial suspension. Plants were sprayed with water 24 hours after treatment and were covered with polythene bags to provide high moisture level. Data for disease incidence [4] was measured after 5, 10 and 15 days.

\section{Data Analysis}

Data obtained from all parameters was subjected to complete randomized design (CRD) as described by Steel et al. [17]. To determine the significant differences, least significant difference (LSD) design was applied. All the statistical tests were performed by using SAS/STAT statistical software [16]. 


\section{Results}

All the treatments $(\mathrm{T})$, concentrations $(\mathrm{C})$ and their interactions expressed significant results against Xac. Maximum inhibition zone was expressed by combination of Flare and Copper hydroxide (5.02) followed by Flare (4.23) and copper hydroxide (3.781) $\mathrm{cm}$ as compared to control (Table.1 \& Figure 1).

Table 1. In-vitro evaluation of different chemicals against Xanthomonas axonopodis, pv. citri

\begin{tabular}{|c|c|c|}
\hline Sr.\# & Treatments & Inhibition zones (cm) \\
\hline $\mathrm{T}_{1}$ & Flare + copper hydroxide & $5.023 \mathrm{a}$ \\
\hline $\mathrm{T}_{2}$ & Flare & $4.237 \mathrm{~b}$ \\
\hline $\mathrm{T}_{3}$ & Copper hydroxide & $3.781 \mathrm{c}$ \\
\hline $\mathrm{T}_{4}$ & Control & $0.000 \mathrm{~d}$ \\
\hline & LSD & 0.022 \\
\hline
\end{tabular}

Mean values in the column sharing similar letters do not differ significantly as determined by the LSD test $(\mathrm{P} \leq 0.05)$.

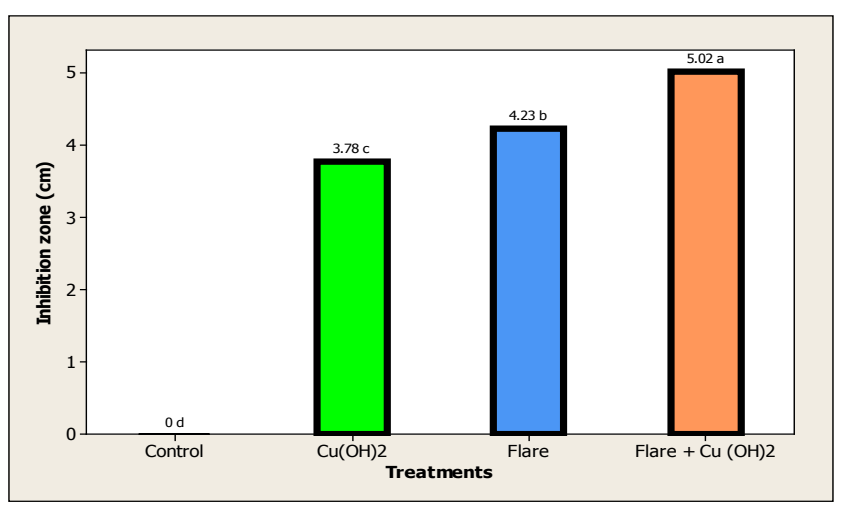

Figure 1. Impact of different chemicals against citrus canker disease caused by Xanthomonas axonopodis in lab conditions

In the interaction between treatments and concentrations $(\mathrm{T} \times \mathrm{C})$, minimum inhibition zone was showed by copper hydroxide (3.62) and Flare expressed (4.39), (4.23) and (4.08) $\mathrm{cm}$ while combination of (Flare + copper hydroxide) expressed maximum $(5.15,5.02$ and $4.88 \mathrm{~cm})$ inhibition zone@ $1,0.2$ and $0.1 \%$ concentrations respectively (Table 2 \& Figure 2).

Salicylic acid, naphthalic acid, copper hydroxide and Flare + salicylic acid were evaluated under greenhouse conditions. Maximum reduction (4.091\%) in disease was expressed by the combination of Flare + salicylic acid (4.09) followed by Flare (4.60), salicylic acid (5.05), naphthalene acetic acid (5.495) and copper hydroxide (5.94)\% as compared to control (Table 3 \& Figure 3 ). In the interaction between treatments and days naphtalic acid expressed 6.10, 5.95 and 5.78, salicylic acid 5.636, 5.500 and 5.350, copper hydroxide 8.34, 8.19 and 8.04 while combination of Flare + salicylic acid exhibited minimum disease incidence of $4.240,4.086$ and $3.946 \%$ after 5,10 and 15 days of application (Table 4 \& Figure 4).
Table 2. Impact of interaction between treatments and concentration against, $X$. axonopodis pv. citri

\begin{tabular}{|c|c|c|c|c|}
\hline \multirow{2}{*}{$\begin{array}{c}\text { Sr. } \\
\text { No. }\end{array}$} & \multirow{2}{*}{ Treatments } & \multicolumn{3}{|c|}{$\begin{array}{c}\text { Inhibition zones (cm) at different } \\
\text { concentrations }\end{array}$} \\
\cline { 3 - 5 } & & $1 \%$ & $0.2 \%$ & 0.1 \\
\hline $\mathrm{T}_{1}$ & Flare $+\mathrm{Cu}(\mathrm{OH})_{2}$ & $5.156 \mathrm{a}$ & $5.026 \mathrm{~b}$ & $4.886 \mathrm{c}$ \\
\hline $\mathrm{T}_{2}$ & Flare & $4.396 \mathrm{~d}$ & $4.230 \mathrm{e}$ & $4.086 \mathrm{f}$ \\
\hline $\mathrm{T}_{3}$ & $\mathrm{Cu}(\mathrm{OH})_{2}$ & $3.936 \mathrm{~g}$ & $3.780 \mathrm{~h}$ & $3.626 \mathrm{i}$ \\
\hline $\mathrm{T}_{4}$ & $\mathrm{Control}$ & $0.000 \mathrm{j}$ & $0.000 \mathrm{j}$ & $0.000 \mathrm{j}$ \\
\hline \multicolumn{4}{|c|}{0.0389} \\
\hline
\end{tabular}

Mean values in the column sharing similar letters do not differ significantly as determined by the LSD test $(\mathrm{P} \leq 0.05)$.

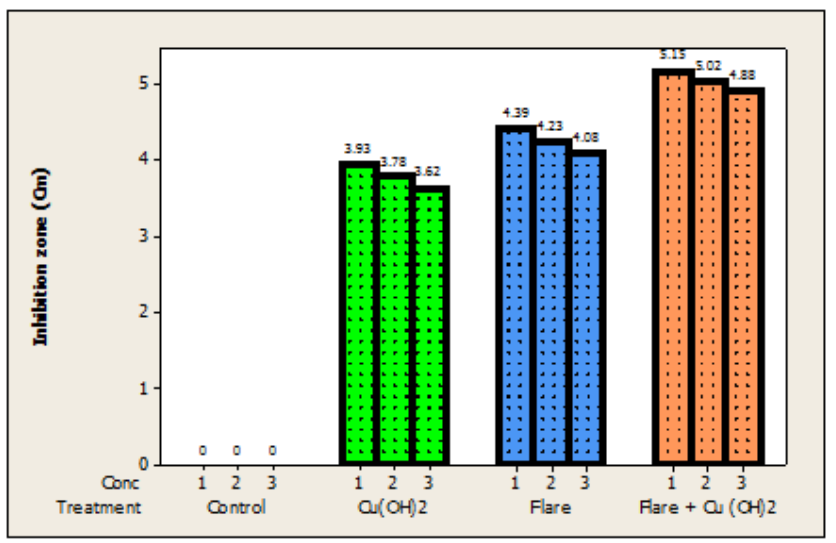

Figure 2. Interaction between treatment and concentration to control inhibition zone caused by $X$. axonopodis pv. Citri in lab conditions

Table 3. Evaluation of different chemicals and plant activators against citrus canker, disease under greenhouse conditions

\begin{tabular}{|c|c|c|}
\hline Sr. \# & Treatments & Disease incidence (\%) \\
\hline $\mathrm{T}_{1}$ & $\mathrm{Cu}(\mathrm{OH})_{2}$ & $5.94 \mathrm{~b}$ \\
\hline $\mathrm{T}_{2}$ & Naphthalene acetic acid & $5.49 \mathrm{c}$ \\
\hline $\mathrm{T}_{3}$ & Salicylic acid & $5.05 \mathrm{~d}$ \\
\hline $\mathrm{T}_{4}$ & Flare & $4.60 \mathrm{e}$ \\
\hline $\mathrm{T}_{5}$ & Flare + Salicylic acid & $4.09 \mathrm{f}$ \\
\hline $\mathrm{T}_{6}$ & Control & $8.19 \mathrm{a}$ \\
\hline & LSD & 3.987 \\
\hline
\end{tabular}

Mean values in the column sharing similar letters do not differ significantly as determined by the LSD test $(\mathrm{P} \leq 0.05)$

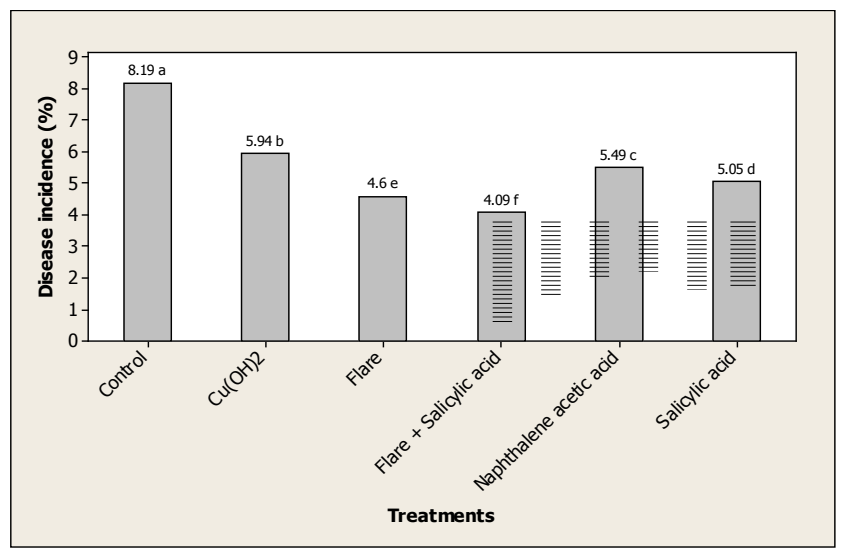

Figure 3. Impact of different chemicals to control disease incidence caused by $X$. axonopodis pv. citri in green house conditions 
Table 4. Impact of interaction of different treatments and days on citrus canker disease incidence under greenhouse conditions

\begin{tabular}{|c|c|c|c|}
\hline \multirow{2}{*}{ Treatments } & \multicolumn{3}{|c|}{ Disease incidence (\%) } \\
\cline { 2 - 4 } & $\mathbf{D}_{\mathbf{5}}$ & $\mathbf{D}_{\mathbf{1 0}}$ & $\mathbf{D}_{\mathbf{1 5}}$ \\
\hline $\mathrm{Cu}(\mathrm{OH})_{2}$ & $6.100 \mathrm{~d}$ & $5.950 \mathrm{e}$ & $5.783 \mathrm{f}$ \\
\hline Naphthalene acetic acid & $5.636 \mathrm{~g}$ & $5.500 \mathrm{~h}$ & $5.350 \mathrm{i}$ \\
\hline Salicylic acid & $5.196 \mathrm{j}$ & $5.056 \mathrm{k}$ & 4.9161 \\
\hline Flare & $4.750 \mathrm{~m}$ & $4.600 \mathrm{n}$ & $3.950 \mathrm{o}$ \\
\hline Flare + Salicylic acid & $4.240 \mathrm{p}$ & $4.086 \mathrm{q}$ & $8.043 \mathrm{c}$ \\
\hline Control & $8.346 \mathrm{a}$ & $8.196 \mathrm{~b}$ & \\
\hline LSD & & & \\
\hline
\end{tabular}

Mean values in the column sharing similar letters do not differ significantly as determined by the LSD test $(\mathrm{P} \leq 0.05)$

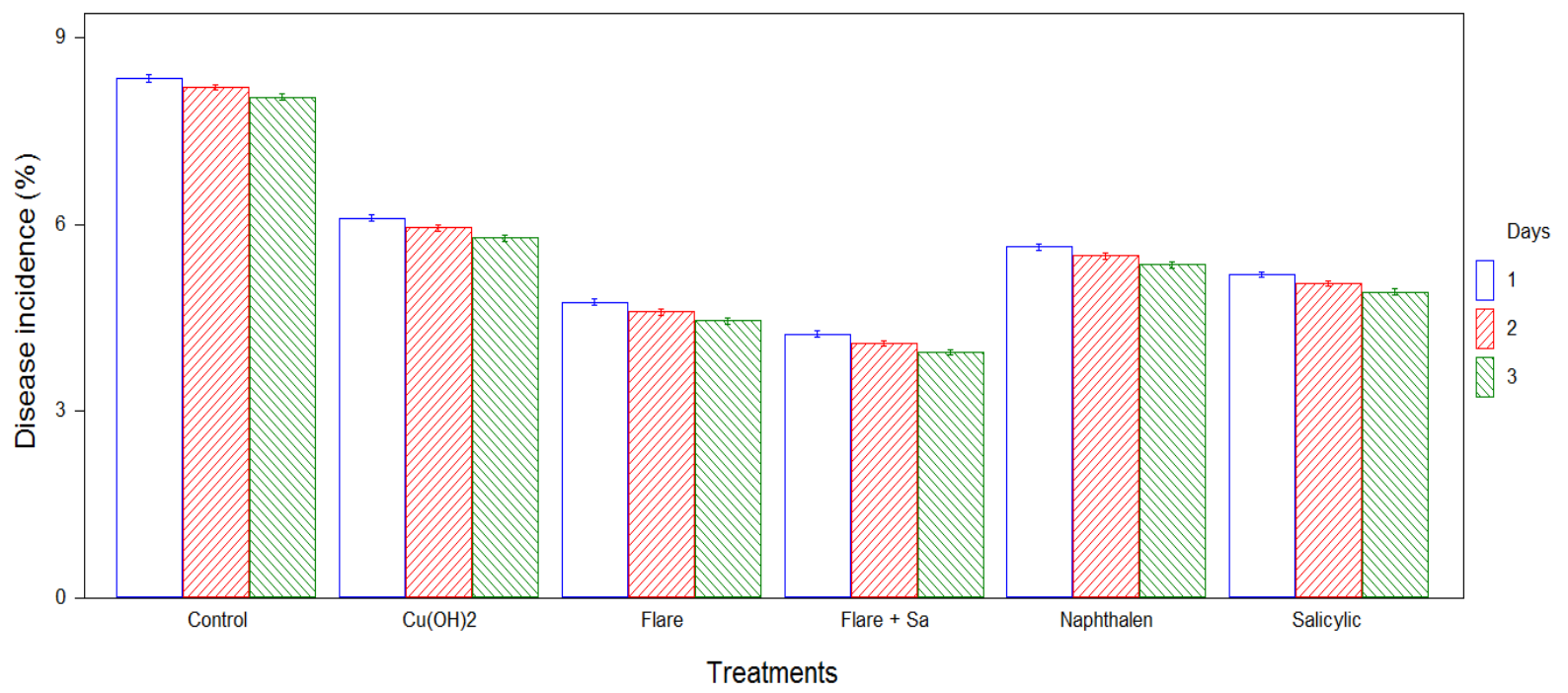

Figure 4. Interaction between treatment and days to control disease incidence caused by X. axonopodis pv. Citri in green house conditions

\section{Discussion}

Citrus canker (Xanthomonas axonopodis pv. citri) causes heavy economic losses to a variety of citrus species and plants of Rotaceous family. A number of management strategies are available but resistant cultivars are the only durable, reliable, easy and economical way to solve the problem of citrus canker disease. Previously recognized commercial resistant cultivars now have become susceptible due to the emergence of new lethal strains of pathogen [5]. One approach to restore citrus productivity is the removal of inoculum sources through complete bark horning, followed by judicious application of chemical (protective copper and insecticide) sprays, and strict adherence to field sanitation. Applications of copper sprays at regular intervals suppress the citrus canker disease significantly [3] but continuous applications of copper compounds induce resistance in bacterial $(\mathrm{Xac}$ ) population and have drastic impact on environment and human beings. Due to this reason this study was carried out to evaluate the potential of copper and streptomycin along with plant activators to avoid resistance in bacteria.

Naturally plants survive in response to attack of various microbes that are a big threat for their survival. Still active and passive defense barriers employed by host plant rendered harmless of many of these microbes. Defense system of resistant cultivars is activated at appropriate time and in sufficient magnitude which is necessary for the suppression of the advancement of pathogen and results into decreased or no disease. In susceptible cultivars, however general defense genes are present but these are not able to block the advancement of pathogen and disease progress as these are activated late or due to their low expression magnitude. It is the need of the hour to make susceptible high yield citrus cultivars resistant against citrus canker disease through application of biotic/ abiotic plant activators. So in present study copper hydroxide $\{\mathrm{Cu}$ $\left.(\mathrm{OH})_{2}\right\}$ and Flare (streptomycin sulphate) alone and combination were evaluated under lab. conditions while under greenhouse conditions salicylic acid (SA), naphthalene acetic acid (NA) alone and in combination ( Flare + SA) were studied. Maximum inhibition zone was expressed by combination of Flare $+\mathrm{Cu}(\mathrm{OH})_{2}$ while under greenhouse condition maximum reduction in disease was expressed by combination of SA + Flare. Outcomes of the present study are supported by the work of Baysal et al. [2] who observed that combination of streptomycin and copper hydroxide exhibited maximum inhibition zone in-vitro and 
these chemicals proved to be less effective. But combination of antibiotics and fungicides significantly decrease the disease incidence agents. SA and streptomycin sulphate created induced resistance in citrus plants stimulated by specific environmental stimuli where by, the plant's intrinsic defenses are potentiated against consecutive biotic challenges [20]. This boosted state of resistance is effective against an extensive assortment of pathogens and parasites [24].

\section{REFERENCES}

[1] J.C. Barbosa, N. Gimenes-Fernandes, C.A. Massari, A.J. Ayres. Incidência e distribuição de cancro cítrico em pomares comerciais do Estado de São Paulo e sul do Triângulo. Mineiro. Summa Phytopathology. 27:30-35, 2001.

[2] O. Baysal, C. Turgut, G. Mao. Acibenzolar-S-methyl induced resistance to Phytophthora capsici in pepper leaves. Biologia Plantarum. 49:599-604, 2005.

[3] F. Behlau, J.R. Belasque, J. B. Filho, A. Graham, J. H. Jr. Leite, T.R. Gottwald. Copper sprays and windbreaks for control of citrus canker on young orange trees in southern Brazil. Crop Protection. 27:807-813, 2008.

[4] J. Chen, Y. P.F. Wen, W.F. Kong. Effect of salicylic acid on phenylpropanoids and phenylalanine ammonia-lyase in harvested grape berries. Postharvest Biology and Technology. 40:64-72, 2005.

[5] Das, A.K. Citrus canker: A review. Journal of Applied Horticulture 5(1):52-60, 2003.

[6] S. Dutta, R.P. Singh and J.K. Jindal. Effect of antagonistic bacteria and plant defence activators on management of bacterial leaf spot of mungbean. Indian Phytopathology. 58(3):54-58, 2005.

[7] J.H. Graham, M.E. Myers. Soil application of SAR inducers imidacloprid, thiamethoxam, and acibenzolar-S-methyl for citrus canker control in young grapefruit trees. Plant disease. 95:725-8, 2011.

[8] Q. Hayat, S. Hayat, M. Irfan and A. Ahmad. Effect of exogenous salicylic acid under changing environment: A review. Environmental and Experimental Botany. 68: 14-25, 2010.

[9] M. Iriti, F. Faoro. Benzothiadiazole(BTH) induces cell-death independent resistance in Phaseolus vulgaris against Uromyces appendiculatus. Journal of Phytopathology. 151:171-180, 2003.

[10] G. Jakab, V. Cottier, V. Toquin, G. Rigoli, L. Zimmerli. $\beta$-Aminobutyric acid-induced resistance in plants. European Journal of Plant Pathology. 107(1):29-37, 2001.

[11] H. Liu, W. Jiang, Y. Bi, Y. Luo. Postharvest BTH treatment induces resistance of peach (Prunus persica L. cv. Jiubao) fruit to infection by Penicillium expansum and enhances activity of fruit defense mechanisms. Postharvest Biology and Technology. 35:263-269, 2005.

[12] Malolepsza, U. Induction of disease resistance by acibenzolar- S-methyl and o-hydroxyethylorutin against Botrytis cinerea in tomato plants. Crop Protection. 25:956962, 2006.

[13] P. N. Nikhil, F.B. Thomas, Q. Jianwei, and A. Mark. Estimation of citrus canker lesion size using hyperspectral reflectance imaging. International Agricultural Engineering Journal. 22(3):41-45, 2013.

[14] M. Prakash, and N. Karmegam. In-vitro antibacterial activity of certain plant extracts against plant disease causing bacteria isolated from citrus plant. International Journal of Current Microbiology and Applied Sciences. 1(1):1-11, 2012.

[15] D.A.M.F. Rinaldi, and R.P. Leite, Jr. 2000. Adaptation of Xanthomonas axonopodis pv. citri.

[16] SAS Institute, 1990. SAS/STAT Users Guide Version 6.SAS Institute, Cary, NC, USA.

[17] R.G.D. Steel, J.H. Torrie, A.D. Dickey. Principles and procedures of statistics, a biometrical approach. 3rd edition. McGraw-Hill Co. Inc., New York NY, 1997.

[18] S.J. Seraj. Synthetic plant activators for crop disease management. A review. International Journal of Pharmaceutics. 2(1): 19-28, 2014.

[19] L.C. van Loon, M. Rep and C. M. J. Pieterse. Significance of inducible defense-related proteins in infected plants. Annual Review of Phytopathology. 44(1):135-162, 2006.

[20] H. Vanacker, T.L.W. Carver, C.H. Foyer. Early H2O2 accumulation in mesophyll cells leads to induction of glutathione during the hypersensitive response in the barley-powdery mildew interaction. Plant Physiology. 123:1289-1300, 2000.

[21] P. Vidyashekaran. Concise Encyclopedia of Plant Pathology. Viva Books New Delhi, 2004.

[22] P. F. Wen, J. Y. Chen, W.F. Kong, Q. H. Pan, S. B. Wan, W. D. Huang. Salicylic acid induced the expression of phenylalanine ammonia-lyase gene in grape berry. Plant Science. 169:928-934, 2005.

[23] D. Wendehenne D, J. Durner, Z. Chen, D.F. Klessig. Benzothiadiazole, an inducer of plant defenses, inhibits catalase and ascorbate peroxidase. Phytochemistry. 47:651$657,1998$.

[24] H. Zhao, B.C. Wang, H.C. Zhao, J.B. Wang. Stress stimulus induced resistance to Cladosporium cucumerinum in cucumber seeding. Colloids Surf B: Biointerfaces 44:36-40, 2005.

[25] Z. Kiraley. Current topics in plant Pathology. Akedemiai Kiado, Budapest, 443, p, 1977. 